\title{
Judicial Cooperation with Foreign Authorities in Criminal Matters in Albania
}

\author{
Klodjan Skenderaj
}

\section{Ejona Bardhi}

University of Tirana, Mother Teresa Square 4, Tirana 1010, Albania

DOI: https://doi.org/10.36941/jicd-2021-0017

\section{Abstract}

The Code of Criminal Procedure is the basic law that regulates jurisdictional relations with foreign authorities in criminal matters in Albania. This Code defines the instruments of judicial cooperation, the manner and procedure of how judicial cooperation is carried out and what are the authorities for the implementation of judicial cooperation. According article 10 of the Code of Criminal Procedure it is guaranteed the compliance of international agreements, principles and norms of international law, accepted by the Albanian state, in accordance with the constitutional principle stipulated by Article 116 of the Constitution of the Republic of Albania. This paper will analyze extradition as a traditional means of judicial cooperation in criminal matters, legal provisions, domestic judicial practice, but also the latest extradition agreement concluded between Albania and the United States of America.

Keywords: Code of Criminal Procedure, Albania, instruments of judicial cooperation

\section{Introduction}

Extradition is a form of judicial cooperation in the criminal field, through which a state agrees to extradite to another state a person located in its territory who is being prosecuted or is being tried for committing a criminal offense or is wanted for execute a criminal sentence in the respective state. Extradition as an institution of procedural law 
aims at punishing the perpetrator of the criminal offense, in cases when he escapes from one state to another or serving a certain sentence in cases when he tries to avoid punishment. Extradition is therefore considered as a legal mechanism by which states assist each other in conducting criminal proceedings or executing criminal sanctions. Article 488 of the Criminal Code stipulates that the transfer for a person to another country can be made by the procedure of extradition.

\section{Rules on Which Extradition is Based According to Albanian Legislation}

A first rule that applies to extradition concerns the principle of specificity or in other words the principle of specialty. Under this principle, the demanding state can prosecute the extraditee only for the offense for which the extradition was granted (Skrame, Boriçi, \& Corri, 2019). Pursuant to Article 14 of the Convention on Extradition, reformulated by Article 3 of the Fourth Additional Protocol, ${ }^{1}$ it si mentioned that for a person that is extradited it is forbidden to be detained for any cause except this cases: First, when the state that has submitted is agreed. Second, when the person, has not leaves the within thirty days of his final discharge, or has returned to that territory after leaving it.

According article 490 of Criminal Code is provided that the extradited person can not be transferred to a state for an offence commited before the request of extradition. This limitation shall be not considered ${ }^{2}$ : a) when the extraditing party gives express consent that the extradited is prosecuted even for another criminal offence and the extradited does not oppose; b) when the extradited, although he/she was able, has not left the territory of the country to which he/she has been transferred, after forty-five days from his release or when after leaving it, he/she has returned voluntarily.

It is noted that there are some peculiarities regarding the Convention on Extradition and the Code of Criminal Procedure, regarding exceptions to the implementation of the principle of specialty. First, the period within which the extradited person has the right to leave the receiving State is 45 days under the Code and 30 days under the Convention. Second, the Code of Criminal Procedure explicitly requires the consent of this person and not just the consent of the extraditing country, as required by the Convention. Regarding these differences, based on the constitutional norms in Albania, according to which, international agreements ratified by law have priority over domestic laws that do not comply with them, it is concluded that the Convention on Extradition has priority over the code of criminal procedure, in cases of extradition of persons from Albania to a State party to the Convention.

Double jeopardy means that the offense must be provided for as such by the legislation of both countries involved in the extradition procedure. With regard to

\footnotetext{
${ }^{1}$ Stipulated in Vienna, on 20.11.2012

${ }^{2}$ Paragraph 2 of article 490 of Criminal Procedure Code.
} 
paragraph 1 of Article 2 of the Convention on Extradition, the Republic of Albania does not recognize minimum limits on the extent of imprisonment for the effects of extradition. The Albanian state recognizes this declaration as valid only in terms of reciprocity. Whereas, pursuant to Law no. 10193, dated 03.12.2009 "On jurisdictional relations with foreign authorities in criminal matters", the extradition of a person to a foreign state is allowed when: a) Albanian legislation provides for a criminal offense punishable by imprisonment of not less than one year; b) the remaining part of the sentence given by a final court decision is at least 4 months, at the time of submitting the request for extradition; $c$ ) the prosecution or execution of a criminal sentence is not provided for under the legislation of the requesting State.

According to the rule of prohibiting extradition for acts of a political nature, it is provided that extradition may not be allowed when the act for which the person is requested is considered by the state to which the request for extradition is addressed, as a political offense or as an offense related to a political offense. The same rule applies when the state to which the request for extradition is addressed has good reason to believe that the request for extradition for a non-political criminal offense was filed in order to prosecute or punish the person, for reasons related to race, religion, and nationality, or political opinions. The political reasons of the requesting state constitute an obstacle to the extradition of the person. Although there is no definition of political offenses, international acts provide for some exceptions, i.e. which offenses are not considered political offenses.

Thus, the assassination of the head of state or his family is not considered a political act. Crimes against humanity, violations of the Geneva Convention and any other comparable violation of the right to war are not considered political offenses. However, the assessment of whether or not the criminal offense is political is left to the state to which the extradition request is addressed. Furthermore, they are not considered political acts, acts with terrorist intent, according to the European Convention for the Suppression of Terrorism. ${ }^{3}$ According to this convention, acts with terrorist intent are not considered political acts, nor acts related to a political act, nor acts motivated by political intent.

Another rule relates to non-discrimination, according to which extradition is not permitted when it is assessed that a person is required to be persecuted or discriminated against because of race, religion, gender, nationality, political beliefs, personal or social status or severe, inhuman or degrading punishments or treatment. In relation to this principle, the motives for extradition are of great importance, which must be assessed on a case-by-case basis in relation to the requesting State in terms of both its social and political conditions. Religious and racial policies existing in the requesting State are taken into account.

\footnotetext{
${ }^{3}$ This Convention has been ratified by Law no. 8642, dated 13.07.2000
} 
Examination of the request for extradition is not a basic trial for the criminal offense attributed to the requested person. In cases of review of the request for extradition, the court decides whether or not to accept the request based on the analysis of two criteria: first, does not assess the existence or not of the accusation and does not analyze the evidence, and second, in the request for extradition, the requesting state shall provide for the circumstances of the commission of the criminal offense, in order to be as exhaustive as possible to the requested state regarding the guilt or the degree of involvement of the person in the commission of the criminal offense. It should be noted that these circumstances are not subject to adjudication by the judicial authorities of the requested country. In the case of an extradition request due to the execution of a final sentence decision, we are faced with a final criminal judgment, which is not reviewed by the court of the requested state. The disposition of the competent court of the requesting party is taken for granted. The authorities of the requested State may not indict, alter or assess the legal character of the offense, nor question the manner in which the matter was resolved. In other words, the review of the extradition request constitutes a formal judgment regarding the fulfillment of the legal requirements of the extradition request.

The rule of non-extradition of citizens is related to the fact that every country has the right to reject the extradition of its citizens. This rule is not binding, as states are recognized the right to act differently, under bilateral agreements. The Republic of Albania has made a statement regarding this norm, stating that it refuses the extradition of its citizens, unless otherwise provided in the international agreement, where the Albanian state is a party. The same regulation is stipulated in Article 491 paragraph 8 of the Criminal Procedure Code, where the Republic of Albania has waived the prohibition on non-extradition of its citizens, pursuant to the principle of reciprocity, by concluding bilateral international agreements with the United States of America, with the United Kingdom, with Italy and Kosovo.

The ne bis in idem rule allows for the refusal of extradition to a person who is being prosecuted by the requested State for one or more of the offenses for which extradition is sought. Article 11 letter d) of the Code of Criminal Procedure provides for the prohibition of extradition if the person requested has been tried by an Albanian court for the same criminal offense for which extradition is requested. The same regulation is found in Article 491 of the Criminal Code, which again provides for non-extradition in cases where the requested citizen has been prosecuted or tried in Albania even though the criminal offense was committed abroad.

Subject to the paragraphs added to this Protocol, the extradition of a person against whom a final judgment has been given in a third State Party to the Convention for the offense or offenses for which extradition has been sought shall not be permitted if: a) innocence has been established; b) if the term of imprisonment has been fully executed or has been pardoned or amnestied, either in full or only for the non-executed part; c) found guilty, but without punishment. According to this principle, a foreign 
citizen who has committed a criminal offense in his country and is located in Albanian territory will not be extradited if this offense has been amnestied in Albania. This rule is stipulated by article 491, point dh) of the Criminal Code where it is sanctioned that Extradition may not be granted when the Albanian State has issued an amnesty for this criminal offence. Regarding the interpretation of the principle ne bis in idem, ie if this principle applies when we are dealing with material criminal offenses with the same facts, when identical legal qualifications are encountered or when violations of the same values are encountered, the position has been held that it is enough that actions or omissions committed to be the same. This is because the legal qualification of the criminal offense does not matter; it is enough for the facts to be the same.

\section{Extradition Procedure}

The extradition procedure means the performance of a series of actions by both the authorities of the requesting State and the authorities of the requested State. According to the Code of Criminal Procedure but also the international legislation, that regulates extradition, two types of extradition are provided. Firstly, we have extradition abroad or passive extradition and secondly, extradition from abroad or in other words passive extradition (Hoxha, 2010). The request for extradition is addressed to the requested state through diplomatic channels. The requesting state must be a party to the agreement in the framework of the Europe Convention but also its additional protocols. Paragraph 1 of Article 489 of the Code of Criminal Procedure stipulates that the request for extradition be addressed to the Ministry of Justice. In addition, Article 12, point 1 of the European Convention on Extradition stipulates that the request for extradition is prepared in writing and submitted through diplomatic channels. This provision also allows for other ways of submitting the request where the requesting State and the requested one by bilateral agreements determine the procedures for submitting the request for extradition.

With regard to extradition abroad, it is initially required that both the requesting country and the requested country must have signed the international agreement. Therefore, in this case the Albanian state must verify the fact whether the state requesting extradition is a party to the multilateral agreements in which Albania has ratified, more specifically the Council of Europe Convention on Extradition and its two additional protocols, or if there is a bilateral agreement between the two states. Therefore, it must be verified whether the Albanian state has entered into an agreement or more precisely is a party to the requesting extradition state. If there is no international agreement between the two countries then the Albanian authorities will have to reject the extradition request. The lack of agreement between the states as a condition for accepting the extradition request is also provided for in Article 11 of the Criminal Code. The request for extradition must have attached a series of documents such as: a copy of the decision on imprisonment or other acts; the main data on the 
criminal offense against the person requested to be extradited, on the time of the commission of the criminal offense but also the place of commission of the criminal offense; the legal basis applicable in the present case according to the legislation of the requesting state; the generalities (personal data) of the person for whom extradition is requested as well as data on his / her citizenship.

It should be noted that the main institutions that administer the extradition procedure are the Ministry of Justice and the Prosecution. Pursuant to Article 489 of the Criminal Code, extradition is allowed only based on a request to the Ministry of Justice. The Ministry of Justice is the only authority that can decide whether to grant an extradition request. Meanwhile, after the Ministry of Justice granted the request for extradition, it is the prosecution, which implements this procedure. This means that the competent prosecution proceeds with the performance of a series of actions towards the identification of the person against whom extradition is requested and, subsequently, with a request to the court to allowing the extradition of the requested citizen. Subsequently, after reviewing the extradition request, the court may decide whether to accept the extradition request of the requested person.

Meanwhile, regarding the extradition abroad, Article 6 of the Criminal Code stipulates that for criminal offenses committed by Albanian citizens, or foreign citizens or stateless, in the territory of the Republic of Albania, Albanian law apply. In many cases, we are faced with situations where different citizens commit a criminal offense in Albania and then to escape prosecution or punishment leave the Albanian territory. The surrender or extradition of the citizen requested by the Albanian authorities is required precisely to enable the confrontation with justice. In this situation, the Ministry of Justice, as the central authority based on the request of the competent prosecution, addresses a request for extradition to the competent authorities of the country where the person for whom the extradition is requested is located. A number of supporting documents are attached to the extradition request. In cases when the foreign state accepts the request for extradition of the requested person, but sets certain conditions, the Ministry of Justice is the responsible institution, which decides on the acceptance or not of the set conditions. If the Ministry of Justice accepts the extradition under certain conditions from another state, then the prosecution and the court are obliged to respect the accepted condition.

Regarding the procedure to be followed in case of an extradition request from abroad, the Code of Criminal Procedure stipulates that in cases when it receives an extradition request from a foreign country, the Ministry of Justice, if it does not reject it, forwards the acts within 10 days to the prosecutor at the competent court, through the General Prosecutor. The prosecutor orders the presence of the interested party to identify him and obtain the eventual consent for extradition. The interested party is informed that he has the right to be assisted by a lawyer. Three months from the date when the request for extradition arrived, the prosecutor parks the request for extradition to the court. However, in many cases, at the request of the Ministry of 
Justice filed through the prosecutor against the person for whom extradition is requested, restrictive measures may be taken to restrict the personal freedom of the person against whom extradition is requested. This is in order for the latter not to avoid the requested extradition. In these cases, the court in carefully determining whether or not to impose a personal security measure should carefully analyze the conditions and criteria for imposing a security measure, starting with a reasonable suspicion that he may have committed the criminal offense, the existence of the criminal offense as and the punishment of the person against whom the imposition of a security measure is requested.

The security measure can be set even before the extradition request comes to you. In this case, Article 494 of the Criminal Code provides that at the request of a foreign state, submitted by the Ministry of Justice through the prosecutor to the competent court, the court may temporarily impose a coercive measure, before the extradition request arrives. In these cases the security measure can be imposed mainly in three cases: first, when the foreign state has declared that a measure of restriction of personal liberty or a decision of imprisonment has been taken against the person and that it intends to submit a request for extradition; second, when the foreign state has provided detailed data on the criminal offense and sufficient elements to identify the person; third, when there is a risk of escape.

The jurisdiction to impose the security measure belongs, in turn, to the district court in whose territory the person has his domicile, residence or dwelling or to the court of the judicial district where he is located. In case the jurisdiction cannot be determined in the ways indicated above, then the jurisdiction belongs to the Tirana District Court. Ministry of Justice notifies the foreign state for the temporary implementation of the coercive measure and eventual seizure.

The court gives a decision in favor of extradition when there is a coercive measure against the requested person, when there is significant evidence of guilt or when there is a final sentence. Meanwhile, the court issues a decision against extradition when there are cases provided for non-acceptance of the extradition request.

The Ministry of Justice must dispose of the extradition within thirty days from the date the decision becomes final. At the end of this period, even when not available to the Minister, the person for whom extradition is requested, when there is a coercive measure in charge of the requested person, is released. The person is released even in case of rejection of the extradition request.

The Ministry of Justice shall notify the requesting State of the decision and when it is positive, the place of delivery and the date from which it will be possible to act.

\section{Extradition Agreement between Albania and the United States of America}

The extradition institute finds the first legal regulation between Albania and the USA in the bilateral agreement or the extradition treaty between the Kingdom of Albania and 
the United States of America of $1933^{4}$. Characteristic of this agreement is related to the fact that it applies to a wide range of criminal offenses starting with murder, grievous bodily harm, violent embarrassment, kidnapping or hostage-taking, bigamy, counterfeiting of coins, etc. However, Article 3 of the agreement expressly provided that there could be no extradition in connection with political offenses committed prior to extradition. Whereas the right to decide whether the offense for which the person was requested was of a political nature belonged to the authorities of the country where the person for whom extradition is sought is located. At the same time, it was also provided that there could be no compulsory extradition of the citizens of the countries signing the extradition agreement, except in cases when the citizenship was obtained after the commission of the criminal offense for which extradition is requested. Article 13 of the 1933 agreement provided that the agreement has a term of 5 years and if at the end of the aforementioned term neither party expressed the will to terminate the agreement, then the agreement will be valid for up to one year after the notification of one by the parties that it withdraws from the agreement. Therefore, according to this forecast, the extradition agreement had an unlimited time span, where we recall that in terms of extradition of Albanian citizens to the US, this agreement was implemented until recent years.

Meanwhile, with Law no. $67 / 2021^{5}$, the Assembly of Albania ratified the "Extradition Treaty between the Government of the Republic of Albania and the Government of the United States of America". This treaty, upon its entry into force, replaces the 1933 extradition treaty between the United States and Albania. Under this new treaty, the signatory parties have agreed to extradite persons wanted by the authorities of the requesting state in order to be prosecuted, or to have a security measure applied to them or to serve a sentence for an extraditable criminal offense.

Extraordinary criminal offense shall mean those offenses for which the legislation of both countries provides for imprisonment for a maximum period of over one year or for another more severe sentence. It is also provided that extraditable criminal offenses are criminal offenses related to fraud or evasion of duties, in relation to taxes, customs duties, regardless of whether or not the legislation of the two countries provides the same types of taxes or tax liabilities. Whereas, in this treaty it is systematically stipulated that extradition is not refused based on the criterion of citizenship.

Article 4 of the treaty between Albania and the USA also contains provisions on political and military criminal offenses. Thus, extradition is not accepted if the criminal offense for which extradition is sought is a political criminal offense. With regard to exclusions from the category of political offenses, it is provided that the following are not considered political offenses: first, criminal offenses for which both the requesting State and the requested State have the obligation, under a multilateral international

\footnotetext{
${ }^{4}$ Signed in Tirana on 01.03.1933

${ }^{5}$ Published in the Official Journal no. 90, dated 10.06.2021
} 
agreement, to extradite the requested person or to refer the matter to their competent authorities for the purpose of prosecuting; second, all criminal offenses of murder, intentional injury, causing grievous bodily harm, intentional assault causing grievous bodily harm and grievous sexual assault; third, a criminal offense involving kidnapping or any other means of unlawful deprivation of liberty, including the holding of a person hostage; fourth, criminal offenses involving the placement, use, threat of use or possession of an explosive, incendiary or destructive device or of a biological, chemical or radiological agent, in cases where the device may cause serious bodily harm or cause serious damage to property.

It is also provided in the bilateral treaty that the executive authority of the requested State may refuse extradition for military offenses, which are not criminal offenses under ordinary criminal law.

An extradition-related prohibition is that provided for in Article 5 of the Treaty according to which extradition is refused when the requested person has been convicted or found not guilty in the requested State of the offense for which extradition is sought.

It is not considered convicted or declared innocent when the authorities of the requested state have decided to terminate the criminal proceedings initiated against the requested person or in cases when the requested person is still being investigated by the authorities for the same offenses for which the extradition is requested.

A peculiarity of this new Agreement between Albania and the USA has to do with the statute of limitations, where pursuant to Article 6 of the Agreement the decision of the state requested to accept or not the request for extradition is taken regardless of the legislation of each party with stipulation. This rule is in fact an exception to the general rule followed in cases of extradition where, if according to the legislation of the requested state the criminal offense for which extradition is sought is statute barred, then the extradition of the requested citizen cannot be continued.

The agreement also provides that in the event that the offense for which extradition is sought is punishable by death under the law of the requesting State and is not punishable by death under the law of the requested State, then the executive authority of the requested State may refuse extradition. However, if the requesting State gives a guarantee to the executive authority of the requested State that the death penalty will not be served against the requested person or, if the requesting State, for procedural reasons, fails to give such a guarantee, a guarantee that the death penalty, if given, will not be executed. If the requesting State provides a guarantee, then the requested State grants extradition and the requesting State respects the guarantee.

Regarding the extradition procedure, it is foreseen that all extradition requests are submitted through diplomatic channels and the extradition request must contain the following documents: first, documents, statements or any other type of information describing the identity, nationality and possible location of the requested person; second, information describing the facts of the offense and the procedural background 
of the case; third, the text of the law or laws providing for the offense or offenses for which extradition is sought, and the sentence(s) applicable; fourth, a copy of the decision or arrest or detention order issued by the competent authority as well as information sufficient to serve as a reasonable basis for believing that the requested person has committed the offense or offenses for which extradition is sought.

Meanwhile, regarding the decision on accepting or not accepting the request for extradition, it is provided that the requested state immediately notifies the requesting state through diplomatic channels and other cases, as the case may be, on its decision regarding the request for extradition. If the extradition request is rejected in whole or in part, the requested State shall provide an explanation of the reasons for the refusal. The requested State shall make available copies of the relevant court decisions if requested by the requesting State. If the request for extradition is accepted, the executive authorities of the requesting State and the requested State shall agree on the place and time of delivery of the requested person. If the requesting State does not remove the requested person from the territory of the requested State within the time limit provided for by the law of the requested State, the requested person may be released and the requested State may, at its discretion, may subsequently refuse extradition for the same offense.

\section{Conclusions}

Extradition is the main instrument in the field of jurisdictional relations with foreign authorities in criminal matters. As such, this instrument of cooperation finds a primary regulation in the Convention on Extradition and its additional protocols, but also in the domestic laws of our country such as the Code of Criminal Procedure and the specific law on jurisdictional relations with foreign authorities in criminal matters. In Albania, this institute has found a wide application, and in recent years, it is noticed that our country has signed a series of bilateral agreements with different countries. However, it should be borne in mind that regardless of the bilateral instruments concluded by our country, the main rules provided for in the Convention on Extradition must be respected, as in this way the rights of the persons for whom extradition is sought can be best guaranteed. However, the recent agreement that our country has concluded with the United States is to be welcomed, where according to this agreement, the basic rule that applies is that of reciprocity between the two signatory countries to the agreement.

\section{References}

Skrame, O., Boriçi, F., \& Corri, I. (2019). Albanian legislation and jurisprudence related to extradition. Overview and recent developments. Tirana.

Hoxha, A. (2010). Extradition according to EU legal instruments. Similarities and differences with the instruments of the Council of Europe. Tirana: Morava.

Lara, D. (2019). Comment on Criminal Procedure. Tirana: Morava.

Law no. 10193, dated 03.12.2009. (2009). "On jurisdictional relations with foreign authorities in criminal matters". 
Law no. 67/2021. (n.d.). "On the ratification of the Extradition Treaty between the Government of the Republic of Albania and the Government of the United States of America".

Law no. 67/2021. (n.d.). Law no. 67/2021 "On the ratification of the Extradition Treaty between the Government of the Republic of Albania and the Government of the United States of America".

Law no. 7895, dated 27.01.1995. (n.d.). "Criminal Code of the Republic of Albania", as amended.

Law no. 7905, dated 21.03.1995. (n.d.). Law no. 7905, dated 21.03.1995 "Code of Criminal Procedure of the Republic of Albania", as amended.

Law no. 8642, dated 13.07.2000 . (n.d.). "On the ratification of the European Convention on the Suppression of Terrorism". (01.03.1933). "Extradition Treaty between the Kingdom of Albania and the United States of America ". Tirana. 